\title{
PRIORITIES AND MECHANISMS OF MODERNIZATION OF THE TURKISH HIGHER EDUCATION SYSTEM
}

\section{ПРІОРИТЕТИ І МЕХАНІЗМИ МОДЕРНІЗАЦЇ̈ СИСТЕМИ ВИЩОЇ ОСВІТИ ТУРЕЧЧИНИ}

\section{Volodymyra Fedyna-Darmokhval ${ }^{1}$ Romana Mykhaylyshyn ${ }^{2}$}

DOI: https://doi.org/10.30525/978-9934-588-38-9-17

\begin{abstract}
Relationship between Ukraine and Turkey has the basic objective sense owing of the Ukrainian population on the Turkish lands, economic relation, Turkish oriented tendencies in Ukraine, turcology in our country. The neighborhood with the Osman Empire was important for Ukraine and in the certain periods it was even decisive political and military factor. A lot of Ukrainian people lived on the Turkish territories or migrated their because of economic and political reasons. At the beginning of the XVI century Turkey became one of the greatest exporters of the oriental goods in Ukraine, because our country was also involved to the Turkish import zone from Asia. Orientalisation of the Ukrainian society was due to the Turkish trade. Transit goods passed through Ukraine to Turkey. Political contradictions in Ukraine in the second half of the XVII century stimulated appearance of the Turkish orientation in the midst of the Cossack nobles.

In the XVI-XVII centuries Turkish orientation in Ukraine is observed in the international relations. We can define five stages of Ukrainian migration to Turkey from the XVII-th century till the middle of the XX-th century. The first stage is the compulsory migration of the prisoned zaporizki Cossacks to the Easter regions of the Osman Empire. After some time Cossacks accepted Islam and got some Turkish features but at the same time they preserved certain Ukrainian peculiarities of the everyday life. The second stage - the beginning of the XVIII century Mazepa's political migration.
\end{abstract}

${ }^{1}$ Candidate of Pedagogical Sciences, Associate Professor,

Lecturer at the Department of General Pedagogics and Pedagogics of the Higher Education, Ivan Franko National University of Lviv, Ukraine

${ }^{2}$ Assistant of the Department of General Pedagogics and Pedagogics of the Higher Education, Ivan Franko National University of Lviv, Ukraine 
The third stage - the end of the XVIII century - the Danube Sich. The next stage - Cossack regiments - Cossaks of Sultan, who served him during the Crimean War of the 1853-1856. The last, fifth stage was in the XX-th century - political migration.

Between our two countries happened adjustment of cooperating in the educational sphere and it was really important. And about this factor we are going to speak about.

The object of investigation in this article are preconditions, periods and the tendencies of the formation and development of the Turkish higher education in the XX-XXI centuries.

The aim of the article is to expose there formation tendencies and to make ground for the formation and development of the Turkish educational policy. We shall regard in this article rapid increase of the quality and quantity proofs in the Turkish high education. We will analyze and motivate their adaptation in our educational system.

\section{1. Вступ}

На сучасному етапі відправним моментом стала налагоджена співпраця в освітній сфері між Україною та Туреччиною, яка у 2002 році вилилася у конференцію Міжнародного педагогічного клубу Європейських столиць. Тоді в Анкарі зародився проект «В освіті пліч-о-пліч». Як зазначив керівник відділу Міністерства освіти Туреччини - Омер Балібей, Україна і Туреччина ще тільки починають відкривати для себе те, наскільки вони близькі один до одного. Туреччина в процесі глобалізації та на шляху вступу в $Є С$, намагається максимально розвивати стосунки iз представниками різних національностей і в першу чергу зі своїми сусідами. У зв'язку з цим, Україна є однією з цих країн, з якими протягом останніх років відбувається активна співпраця в сфері освіти. Незважаючи на підписані двосторонні угоди українсько-турецьких взаємини в освітній сфері, вони тривалий час не були наповнені практичним змістом. Конкретним проявом такої співпраці стало створення Міжнародної школи «Меридіан» у 2001р. (засновник Мехмет Гюлер), де працювало

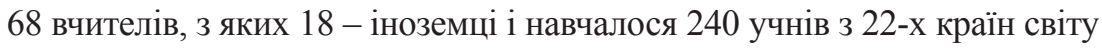
$[1$, c. 6]. Школа була створена спільно українськими та турецькими підприємцями. А в 2003 році з Омер Балібеєм в Києві була підписана угода про співпрацю між освітянськими інституціями обох міст. 
Метою статті є розкрити передумови, реформаційні тенденції й обгрунтувати становлення та розвиток освітньої політики Туреччини.

3 метою чіткого окреслення особливостей проблемного пошуку, нами було залучено методи аналізу та синтезу; з метою дослідження передумов функціонування вищої освіти в минулому та відповідні кількісні та якісні зміни на сучасному етапі, а також для зіставлення їх особливостей, ми застосували історичний та порівняльний методи.

У статті вперше у вітчизняній педагогічній науці проаналізовано освітні тенденції Туреччини в умовах євроінтеграційних процесів, 3 метою налагодження кроскультурного та міжкультурного діалогів між Україною та Туреччиною; обгрунтовано реформаційні кількісні та якісні зміни вищої освіти Туреччини.

\section{2. Налагодження крососвітнього простору між Україною і Туреччиною}

Одним з актуальних питань розвитку вищої освіти в Україні $є$ питання модернізації, наповнення новим змістом, підвищення престижу підготовки майбутніх педагогів. Коли ректори університетів Одеси, Полтави, Вінниці, Глухова, Слов'янська, Чернігова, Ялти, Горлівки, відвідавши Туреччину, були вражені тим, що випускникові університету - молодому спеціалісту престижно отримати місце в загальноосвітній школі, вони зрозуміли, що сучасні стратегії України необхідно спрямовувати на подальший розвиток національної системи освіти, адаптовувати до умов соціально-орієнтованої економіки, трансформувати та інтегрувати в європейське та світове товариство. В турецькій системі освіти відбуваються суттєві переміни, пов'язані зі зміною економічного, соціально-культурного життя, необхідністю приведення педагогічної освіти у відповідність із мінливими вимогами суспільства. Туреччина є державою із специфічним економічним, політичним розвитком та своїми особливостями у педагогічній освіті, про які ми дальше поговоримо.

\section{3. Перші вищі школи Туреччини}

В Турецькій Республіці в 1874 році були 3 вищі школи права, літератури та інженерії, які об'єдналися в установу під назвою Галатасарай Дарульфунуну. У 1912 році відповідно до впорядкувань Мааріфом Назири Емрулахом, Дарульфунун поділили на 5 відділень: відділення 
шаріату, права, літератури, медицини та мови. У 1915 році для дівчат відкрили вищий навчальний заклад Інас Дарульфунну. В період війни 3 курдами Туреччина переживала важкі часи 3 підготовки педагогів. У 38 провінціях і санджаках було 1345 початкових школи, 28 султаніє та 18 шкіл для вчителів. На той час було 3061 вчителів, з яких 871 залишили школу. Згодом у 1921 році Кемаль Ататюр зібрав Конгрес 3 питань освіти, навчання і педагогів.

Отож, у 1869 році у Стамбулі відкрився університет Darülfnün Дарюльфунун, де навчання тривало 3 роки. У цьому університеті був факультет: філософії, літератури, права, математики та природничий. Проте цей університет не був достатньо успішним через важке фінансове становище, не дуже кваліфікованих педагогів та нестачу книг [3, с. 128]. Окрім Дарюльфунун у період Танзимату відкривалися такі вищі школи як Мюлькіє мектебі, Мюлькіє Тиббіє мектебі.

Вже у 19 ст. в Туреччині почалася підготовка вчителів за західним зразком. У 1848 році у Стамбулі відкрили школу для вчителів чоловіків - Darülmuallimin - Дарульмуаллімін, де готували вчителів для початкової освіти - рушдіє, а вже у 1870 році була відкрита школа для жінок вчителів - Darülmuallimat - Дарульмуаллімат, яка готували вчителів окрім як для рушдіє для дівчат, так і для елементарних шкіл. Для майбутніх вчителів (чоловіків) викладалися уроки з культури, методів навчання, а для жінок - майбутніх вчителів - шиття, музику та малювання. Для підготовки вчителів середньої та вищої школи у 1874 році у Дарюльмуаллімін рушдіє відкрили окреме відділення, де викладалися французька мова, хімія, мудрість і товарознавство [3, с. 156].

\section{4. Філософські засади вищої освіти}

Вища освіта у світі із заснуванням університетів не пов'язана (в Болоньї - 1088 р.; Парижі - 1150 р.). Академії у Давній Греції, християнські катедри і монастирі, ісламські медресе - всі вони здійснювали функцію вищої освіти. Університетам було дуже важко відокремитися від цих попередніх форм (медресе, монастирів, академій). Університети мали дещо подібне до цих попередніх форм вищої освіти. В північній Свропі, зокрема в Парижі, викладалися вільні мистецтва: арифметика, логіка, риторика, музика, теологія. В південній Європі Італії - викладалися право та медицина. У 1810 році німецький іде- 
аліст Вільгельм Гумбольд заснував сучасний модерний університет, який від Середньовічного університету відрізнявся тим, що модерні університети мусіли бути зосередженими на дослідженнях, на відміну від старих університетів, в яких просто передавалася інформація. В Середньовічному університеті використовувалися схоластичні методи навчання, а в сучасному - наукові методи.

3 часом створюється модель Американського університету з такими відділеннями як промисловість, сільське господарство, національними відносинами. 3 часом Американська модель - технократична, зосереджена на ринку, конкуренції, гнучкості та свободі, почала витісняти німецьку модель - «знання заради знань». 3 часом вища освіта забезпечила доступ для ії отримання великій кількості осіб. Мартін Тровун зазначав, що система вищої освіти розширивши доступ, поділилася на три фази: елітна (elit), народна (kitlesel), універсальна (evrensel). До 1950-х років в розвинених країнах елітна вища освіта перетворилася на народну. По всьому світу у вищій освіті народність почала кількісно і комплексно зростати. Після Другої Світової війни збільшилася кількість тих, хто здобув народну вищу освіту, а у 1980-х роках почалося обговорення про створення універсальної вищої освіти. Таким чином почалася заміна народної на універсальну вищу освіту. У тих, хто почав здобувати вищу освіту почав збільшуватися середній вік, стало легше жінкам здобувати освіту, люди з різних соціальних верств (farkl1 sosyal sinif), з певним економічно-нестабільним становищем швидше почали здобувати вищу освіту. Для того, щоб вища освіта краще розвивалася, ставилося питання фінансування. В останні роки в світі кількість установ $з$ вищою освітою швидко зростала і державні університети почали менше використовувати державні ресурси, заохочуючи до розвитку власні. Університети приймали інвестиційну допомогу від філантропів та своїх випускників. Актуальними для тих, хто навчався в університетах були технічні знання та ідея навчання впродовж життя. Тому було вирішено повернутися до універсалізації знань, таким чином збільшивши економічне прискорення. Відповідно до цього кількість осіб у групах зростає, оскільки у групи починають брати різних за віком людей. 3 часом дослідницькі центри та університети виходять за межі класичного функціонування, налагоджуючи фінансові зв'язки через використання більше проектів та патентів. Бюджети університе- 
тів і спеціальні джерела керування були в такому безладі, що почався період професійного керування, при якому кількість керівників збільшувалася, а кількість академіків зменшилася. Освіта й дослідження в університетах ставали важливішими.

В європейських країнах була найдинамічнішою економіка і тому кількість студентів з вищою освітою зростала, поряд з цим покращувалася гарантія якісних стандартів. В цих рамках в кількох країнах світу організовувалися відповідні центри гарантії якості (kalite güvencesi). В багатьох країнах світу держава пропонувала спеціальні формати вищої освіти. В попередніх роках у всьому світі робилися прогнози продовження міжнародної вищої освіти [4, с. 48]. Це пояснювалося тим, що в різних країнах університети видавали спільні дипломи, студенти у своїх країнах та за кордоном навчалися кілька семестрів. Кількість студентів, які вчилися у власній країні і підписувалися на програму одержати диплом іншої країни масово зростала. Таким чином передбачалося збільшення навчальних курсів, навчальних установ і академічних досліджень. До 2030 року у Північній Америці, якщо буде продовжуватися така попередня міжнародна співпраця у вищій освіті, в Азії та Європі збільшиться глобальний вплив. Вища освіта стала прогресивнішою (електронною освітою): наприклад, запровадилися масові заняття онлайн (MOOCS), де з різних куточків світу тисячі людей можуть їх одночасно слухати. Зараз постає питання: яка була роль попередніх і яка буде роль наступних університетів?

В середині 21 ст. слід обговорити 4 майбутніх сценарії, моделі вищої освіти: 1) відкрита мережа як модель вищої освіти; 2) підготовка місцевих співтовариств як модель вищої освіти; 3) нова громадська відповідальність як модель вищої освіти; 4) вища освіта як модель фірми [4, с. 52]. Ці моделі у 2007 році запропонувала Організація економіки співробітництва та розвитку OECD - Ekonomik Iş birliği ve Kalkınma Örgütü. Перша модель вищої освіти передбачає міжнародну ситуацію подібно до фахівців, студентів та інших осіб, які налагодять мережу співпраці. Ця модель організації спільної роботи буде базуватися також і на конкуренції. В контексті цієї моделі студенти позбавляються від академічних обмежень, збільшується співпраця міжнародних досліджень, покращується співпраця між установами. Плануються відкриватися нові напрямки підготовки студентів, збільшуватися доступ до культурних та інтелектуальних прав власності. 
Друга модель вищої освіти фокусується на національних та місцевих проблемах, пов'язаних з місцевими та регіональними співтовариствами освіти. В цій моделі акцентуються питання на проблемах міжнародної вищої освіти. Терористичні атаки, війни, зовнішня міграція збільшують хвилювання, відбувається загроза іноземного впливу на ідентичність.

Третя модель вищої освіти полягає у громадській підтримці та фінансовому заохоченні. Установи вищої освіти є бюджетними, але частка громадського фінансування продовжує існувати. Через забезпечення приватними установами і через витрати студентів, доходи університетів, втрачаються межі між приватними і громадськими установами. В деяких країнах в успішній формі можна побачити доктрину нового громадського методу, при якому громадський і приватний сектор разом є джерелом доходів установ.

На думку четвертого сценарію розвитку вищої освіти, обслуговування і дослідження освіти поступово один від одного починає від'єднуватися. Між студентами та академіками дослідниками є жахлива конкуренція. У розвинутих країнах $є$ переваги конкурентоспроможності в тому, що вони вибирають напрямок дослідження: наприклад, в Китаї швидко розвивається наукове сільське господарство; в Індії розвивається програмне забезпечення. На різні університети в регіонах Туреччини, а також на світові університети поширюється американізація: чи через те, що американські університети дають натхнення, чи через те, що інші університети є філіями американських університетів, чи через витік інтелекту, але система американських університетів поширюється. Ця гегемонія (домінування якоїсь країни) певною мірою поширюється і привносить культурні очікування. На противагу користі щодо американізації з прогресивними країнами, між іншими країнами поглиблюється асиметрична залежність стосунків, цілей i 3 точки зору зайнятості відбувається застрягання великих прагнень i проблеми вищої освіти піддаються критиці.

Отож, університетська закоренілість $є$ в минулому, на сьогоднішній день, починаючи з 19 ст. $є$ значення модерних університетів. Університети впродовж двох останніх століть функціонують як національно-державні, задовольняючи національно-культурні потреби студентів. Вища освіта у другій половині 20 ст. здійснює популяризацію, 
де кількість і різноманітність студентів збільшується. Таким чином фінансування стає особливою проблемою установ вищої освіти, формат стосунків між центральними органами і установами вищої освіти набирає змін. Таким чином, для того, щоб вирішити фінансові питання, починається заохочення різних джерел фінансування, відбувається активний пошук спонсорів.

Доступ до вищої освіти відбувається при переході від кількісного до якісного зростання. Після 2-ої Світової війни масштаби вищої освіти збільшувалися, розширювалася кількість населення, спостерігалося процвітання країн. В Туреччині питання доступу до вищої освіти минули і після 1980 року почалися дослідження щодо великих змін у вищій освіті.

Загалом, після 2-ої Світової війни, в цей період відбулися зміни в світовому соціальному процвітанні, збільшилися потреби і спрямування. В цьому напрямку система вищої освіти у всьому світі після 1945 року в чіткій формі розширилася і встановила ширше співробітництво по доступу мас. В період після 2-ої Світової війни, особливо у 1945-1960 рр. загалом освіта у світі змінила траєкторію, вона поширилася і стала доступнішою.

Після 1960 року населення Туреччини складається з населення різних географічних країн і це по різному впливало на доступ до освіти. Демографічні зміни, іншими словами висока смертність і висока народжуваність, низька смертність і низька народжуваність - між країнами спостерігалася різна динаміка населення. У вищій освіті кількість нових студентів, які вступали і випускалися пов'язана 3 демографіч-

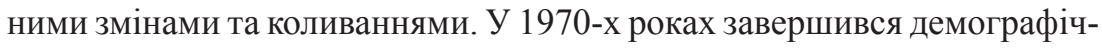
ний перехід. В західних розвинутих країнах відбувся розподіл переваг у конкуренції і збільшилося соціальне процвітання і це їм забезпечило серйозні переваги. Після завершення демографічного переходу у розвинутих країнах, населення почали кликати в університети і це впливало на збільшення стабільності у населення.

\section{5. Динамічність у цифрах}

Якщо проаналізувати народжуваність світу з темпами зростання у періоди 1960, 1980, 2012 роки, то, наприклад, в 1960-х роках загальна народжуваність в Туреччині (Türkiye) збільшилася на 6,3, в Японії - на 2, в Німеччині на 2,4, в США (ABD) - на 3,7, в Мексиці - на 6,8, у Філі- 
пінах на 7,1. В 2012 році в Туреччині - на 2,1; Японії - 1,4; Німеччині 1,4; США - 1,9; В Туреччині чисельність населення збільшилася на 2,5\%, а в 2012 р. - 1,3\%. Мексиці - 2,2, Філіпінах - 3,1 [2, с. 134]. А от що стосується грамотності, то з 1950 по 2010 роки у Туреччині з 1950 по 2010 роки здійснено окремо підрахунки по чоловіках - у 1950 році (45,5\%), жінках (19,4\%), в 2010 році грамотність чоловіків досягла $100 \%$, а в жінок - 90,1\%. Подібно до прогресу у світі, в Туреччині грамотність населення впродовж 60 останніх років зросла з 30 до 95\%. На поч. 1980 - х років половина жінок були позбавлені грамотності, а у 2010 році безграмотність зменшилася до $10 \%$.

Що стосується різниці освітніх рівнів, опис ситуації того як змінювалася кількість тих, хто навчався у різних закладах 1945-2012 рр., то в розвинутих країнах у 1960-1970-х рр. відбувся глобальний перехід до вищої освіти, проте в Туреччині це сталося після 2000 року. До 1990 року доступ до вищої мав обмеження, оскільки виникла проблеми $з$ джерелами фінансування.

У Туреччині у вищій освіті частка тих, хто навчалися у 1950 році становила $1,3 \%$, у 1995 році - стало $18,5 \%$, а в 2012 році їх кількість досягла до 74,9\%. Впродовж 1970-х років частка вищої освіти впала на $6 \%$ і певний час не збільшувалася. Квота студентів університету була визначеною, хоча нові університети відкривалися і кількість нових студентів зростала. В університетах трьох великих Турецьких міст основа гуманітарних та академічних наук накопичувалася в певних географічних регіонах. Нові університети, що відкривалися в різних частинах міста Анадолу, стикалися з певними проблемами навчання, оскільки університети впродовж довгих років залишалися з проблемами становлення кадрів. Незважаючи ні на що, з кожним днем збільшувався попит молоді до вищої освіти. У 1975 році у вищих навчальних закладах навчалося 65 тисяч студентів, проте з 1976 по 1981 роки кількість студентів досягала 36 тисяч 639. Проте вже через чотири роки кількість студентів досягає 156 тисяч 065 осіб.

Що стосувалося ситуації щодо студентів в Україні, то їх кількість збільшилася майже втричі, від 881 тисячі у 1990/1991 роках до 2 млн. 373 тис. у 2007/2008 рр. Подальше зменшення кількості студентів (а за ними - повільне скорочення кількості самих навчальних закладів) пов'язане виключно з демографічною ситуацією. Починаючи з 1991-го року в 
Україні різко скоротилася народжуваність (від 657 тис. дітей 1990 року до 377 тис. у 2001-му, після чого почалося збільшення народжуваності) [2, с. 96]. Тобто, в 2008-му закінчили школу ті, хто народилися у 1991-му, і починаючи від цього року у ВНЗ (спочатку у менш престижних, а потім геть у всіх) почали виникати проблеми 3 нестачею студентів, низьким конкурсом. Відтак - ще нижчими вимогами до студентів. Результатом цього стало те, що вища освіта в Україні нині $\epsilon$ просто обов'язковим атрибутом, а наявність диплому не свідчить про наявність фахових знань [7]. Якщо порівняти нашу країну з Туреччиною, то в останній спостерігаємо значний як кількісний прорив в кількості студентів та внз, а отже це свідчить про якісний склад вищої освіти.

Вища навчальна асамблея (Yüksek Öğretim Kurulu), що була створена у 1981 року в Туреччині, подала університетам певні правила. Проте ця асамблея у 1975 році була відмінена судом, оскільки кількість членів з уряду, які входили в асамблею була більшою, ніж кількість членів з університетів (автономність університетів була суперечливою). Тому у 1974 році був створений Центр студентського між університетського вибору (ÜSYM), проте квота студентів університету не дуже збільшувалася.

В Туреччині був період, коли збільшилася кількість тих, хто хотів вступити в університет. В цей час спостерігається розширення і глобалізація вищої освіти у світі. У другій половині 1970 р. незважаючи на політичну та економічну кризу, центр іспитів та координування встановив своїм методом новий механізм, завдяки якому квота вищої освіти збільшилася і почали створюватися нові університети. В результаті цих змін кількість студентів почала швидко зростати і десь за 5 років кількість нових студентів, які вступили в університет в 3 рази зросла. Ця кількість студентів у 1982 роках рівень 1975 років наздогнала, а у 1984 році 150 тис. досягла, а у 1985 році кількість студентів в 2,5 рази збільшилася [5, с. 134]. Відповідно у 1985 році кількість студентів збільшилася в 4 рази. Після 1980 року стало очевидним збільшення попиту до вищої освіти, тому попит на університетську систему розширився.

Заснування нових університетів в процесі збільшення контингенту, найбільш комплексне зростання було починаючи з 2006 року, особливо між 2006-2008 роками велика кількість нових державних і приватних університетів була створена. У 1982 році було створено 
27 університетів, а в 2013 р. - їх стало 175. Незважаючи на це, впродовж довгих років між пропозицією і попитом були неузгодженості і система вищої освіти була найбільшим джерелом гніту. В період між 1982 і 2005 роками було відкрито загалом 50 нових державних і приватних університети. А впродовж 2006-2013 років - 81 університет. Що стосується України, то на сьогодні мережа вищих навчальних закладів налічує 803 всіх рівнів акредитації та форм власності, у тому числі 325 - 3-4 рівнів акредитації та 478 - 1-2 рівнів акредитації. До державної форми власності належать 215 начальних закладів 3-4 рівнів акредитації та 200 навчальних закладів 1-2 рівнів акредитації; приватної форми власності - 96 навчальних закладів 3-4 рівнів акредитації та 71 1-2 рівнів акредитації. Сучасна мережа вищих навчальних закладів (внз) набагато перевищує потреби України. Наприклад, у більшості країн світу з населенням, сумарним із населенням України за чисельністю і віком, кількість державних внз становить, зокрема, у Великобританії - 96, Франції - 78, Іспанії - 47, Італії - 65.

В останні роки в Туреччині спостерігається відносний баланс між пропозицією - кількістю університетів і попитом - кількістю студентів у системі вищої освіти. Вже на початку 2010 року цей формат почав покращуватися, проте впродовж 30 років така проблема незбалансованості між попитом і пропозицією зберігалася. Між університетами, що відкривалися і університетами, що вже існували, налагоджувалася певна кореляція. Уряд почав відкривати дуже багато нових університетів, система почала розростатися і це потребувало надто багато фінансів. Асамблеї Вищої освіти вдавалося керувати наростаючими проблемами і університети мали змогу покращити свою інфраструктуру. В 1980-х роках приблизно 467 тисяч студентів вступали в університети і лише 9\% з них змогли засвоїти програму вищої освіти. Впродовж 1980-90-х років попит на вищу освіту стабільно зростав. До 1999 року 1 млн. 478 тис. 365 студентів подали заявку на вступ до університету. Того ж року, студентів, які навчалися в університеті було 448 тис. 377.

Згідно $з$ дослідженням Центру вимірювання, вибору і пояснення (Ölçme Seçme Yerleştirme Merkezi) впродовж 1980-2013 років змінювалася загальна кількість тих, хто подав заявку на вступ в університет, так і кількість тих, хто вже навчався в університеті. 
Починаючи з 2006 року багато нових державних і приватних університетів були відкритими. У 1980 році 466 тис.963 особи подали заявку до вступу на вищу освіту, а у 2000 році - їх кількість становила 1 млн. 407 тис. 920 осіб, а вже у 2014 році - 2 млн. В період 80 -х років, кількість тих, хто вступав в університети поступово почала збільшуватися: у 1984 році на 20\%; у 1985 р. - на 10\%; а у 1987 р. - на 25\%. Загалом впродовж 1980-2013 років кількість тих, хто здавав вступні іспити в університети збільшилася в 5 разів [6, с. 33]. В порівнянні 3 кількістю тих, хто заявив про вступ на здобуття вищої освіти, і тих, хто вже навчався - була скромною, проте в останні роки демонструвалося зростання. Наприклад, у 2011 році 768 тисяч кандидатів написала заяву на вступ в університет і лише 400 тисяч - більше половини освоїли університетську програму.

Загалом, система вищої освіти Туреччини незважаючи на деякі проблеми, стабільно покращувалася, а особливо в останні роки. Відповідно до форм навчання і кваліфікаційних рівнів: денна і заочна форми неповної вищої освіти (дворічне навчання) в університеті (ӧn lisans yüzyüze ve açık ögretim); денна і заочна форми повної вищої освіти (чотирирічне навчання) в університеті (lisans yüzyüze ve açı ögretim); аспірантура (yüksek lisans); докторантура (doktora); спеціалізація в сфері медицини (tıpta ihtisas), кількість випускників за 1983 рік по всіх програмах вищої освіти була приблизно 37 тисяч. Через 30 років, тобто у 2012 році їх загальна кількість становила 620 тисяч. Отож, кількість випускників всіх програм протягом років стабільно зростала. 31982 по 1992 роки за сукупністю всіх програм кваліфікаційних рівнів вищої освіти - кількість випускників була 2 млн. 160 тисяч. Впродовж наступних років ця кількість досягла 4 млн. 250 тисяч, які отримали дипломи про вищу освіту. Отож, кількість випускників в перші 20 років кожні 10 років в 2 рази збільшувалася, а в період останніх 10 років у 2,5 рази. Впродовж 30 років дипломи про неповну, повну вищу освіту, аспірантуру, докторантуру і медичну освіту отримало 7 млн.220 тисяч випускників у процентному відношенні - це $76 \%$, з яких 26\% - дипломи неповної вищої освіти, а 43\% - повної вищої освіти. Із всіх випускників 5\% були випускниками аспірантури. Докторські програми та медичну спеціалізацію закінчило 1\%. Щодо заочної форми навчання, то закінчили вищі навчальні заклади і отри- 
мали диплом - 24\%, 3 яких 10\% неповна вища освіта і 14\% - повна вища освіта. У 2011 році відбулися певні зміни [5, с. 136]. Наприклад, випускників неповної вищої освіти денної форми навчання стало $28 \%$ (що на 2\% зросло в порівнянні 3 попередніми роками); $36 \%$ - повної вищої освіти (показники знизилися на 7\%). Щодо заочної форми навчання неповної вищої освіти, то ситуація не змінилася - $10 \%$; а от повна вища освіта зросла на 6\% в порівнянні з попередніми роками. Кількість випускників аспірантури зменшилася на 1\% і становила $4 \%$. В останні 5 років спостерігається тенденція до збільшення випускників заочної форми навчання.

Багато студентів вступали в університети, але закінчувало їх менше, оскільки не справлялися 3 програмами вищої школи. Наприклад, у 1982 році 73 тис. абітурієнтів вступили у вищі навчальні заклади, але лише 37 тис. стали випускниками; у 1990 році - 196 тисяч вступило, 93 тисячі завершили навчання; у 2011 році - 907 тисяч вступило, а закінчили навчання 616 тисяч. Незважаючи на те, що в Туреччині довший час поширювалися проблеми доступу до вищої освіти, в період 1980-2010 років навчання вищої освіти досягло рівня членства в Організації економічного співробітництва та розвитку - OECD Ekonomık Işbirliği ve Kalkınma örgütü. В останні 30 років питання Туреччини тут почали частіше розглядатися.

У 1980-х роках частка навчання вищої освіти у Туреччині була 6\%, у той час коли в Англії - 19\%, Франції - 25\%, США - 53\%, Японії $31 \%$, Росії-45\%, Італії-27\%. До 2005 року Туреччина по брутто (масі) щодо вищої освіти в порівнянні з цими країнами на рівні половини була. Проте в останні роки в Туреччині спостерігається у цій сфері значний стрибок. У 2011 році в Туреччині кількість тих, хто здобув вищу освіту становила $61 \%$, тоді коли у Франції - 57\%, Англії - 61\% і Південній Кореї - 101\% [6, с. 37]. У 2014 році в Туреччині установи вищої освіти вміщували в себе 5 млн.500тис. студентів.

В останні роки в цілому світі спостерігалася тенденція до якісного зростання вищої освіти. В період між 1960-1990 роками в Туреччині демонструється зростання досягнень в системі вищої освіти в суміжності з такими країнами як Далекий Схід і Південна Америка, які після 2000 р. показали значні досягнення. Найбільш комплексне зростання щодо вищої освіти спостерігалося в Китаї, який впродовж 10 років 
досяг рівня 322\%. У Бангладеші, Ірані, Бразилії та Індії зростання відбулося до 100\%. У Туреччині відповідно до інших країн, зростання відбулося найшвидше і досягло рівня $121 \%$. До того ж тенденція до зростання кількості тих, хто оволодіває вищою освітою після 2008 року переживала глобальну фінансову кризу й ймовірно відбулися певні скорочення.

\section{6. Прогностичні міркування}

Вища освіта в період 18-22 ст., як прогнозує, Установа Турецької Статистики (TÜİK Türkiye İstatistik Kurumu), що кожного року в середньому 1 млн. 250 тис. буде студентів, а після 2050 року буде довгий період, що в середньому кожного року буде 1 млн. студентів, що здобуватимуть вищу освіту. Через це проблема доступу до вищої освіти $\epsilon$ важливою і поступово. $Є$ припущення, що в питаннях народжуваності хлопці досягнуть $75,8 \%$, а дівчата - 80,2\%. Прогнозується, що швидкість коефіцієнту народжуваності буде між 14 і 16\% і що загальна кількість населення зросте з 76 до 85 млн. Така демографічна можливість залишиться до 2050 року, завдяки зростання Турецької економіки, інвестиціям, зосередженим на процвітанні освіти через збільшення досліджень та розвитку.

На сьогоднішній день в Туреччині в установах вищої освіти студенти, які отримують першу освіту їх кількість по різних рівнях освіти $\epsilon$ такою: 25\% - неповна вища освіта; $61 \%$ - повна вища; $15 \%$ - магістратура. Студенти, які отримують другу освіту їх кількість по різних рівнях освіти є такою: 39\% - неповна вища освіта; 61\% - повна вища; $0 \%$ - магістратура. Тих, хто навчається на заочній формі навчання: $37 \%$ - неповна вища освіта; 63\% - повна вища. Тих, хто навчається за програмою дистанційного навчання: $45 \%$ - неповна вища освіта; $37 \%$ - повна вища; 18\% - магістратура [5, с. 138]. Отож, зі всіх студентів 41\% вчиться по програмі першої освіти; 12\% - по програмі другої освіти; 47\% на заочній формі навчання і 1\% по програмі дистанційного навчання. По магістерській програмі продовжують вчитися 98\% студентів, які здобувають першу освіту і 2,4\% 3 дистанційної освіти.

Окрім цього варто зазначити, що 5 млн. 089 тисяч 291 студент навчається в державних вищих навчальних закладах; 359 тисяч студентів - у приватних навчальних закладах і 10 тисяч - приватних 
вищих професійних навчальних закладах. Першу освіту здобуває 1млн. 866 тисяч студентів у держаних вищих навчальних закладах, 334 тисячі у приватних і 7 тис. 100 - у вищих професійних закладах. А от другу освіту здобувають 640 тисяч студентів у держаних вищих навчальних закладах, 13 тисяч у приватних і 1 тис. $600-$ у вищих професійних закладах. На заочній формі навчання неповну вищу освіту здобуло 935 тисяч студентів; повну вищу - 1 млн. 610 тисяч $\mathrm{i}$ 39 тисяч навчалося за дистанційною програмою. Загальна кількість студентів, які навчаються у державних вищих навчальних закладах є 93,4\%, 6,4\% у приватних і 0,2\% - у приватних вищих професійних закладах. Всіх студентів, які навчаються в державних вищих навчальних закладах, здобуваючи першу освіту є 37\%; тих, які здобувають другу освіту - 13\%; на заочній формі навчання є 50\% і 0,8на дистанцій формі навчання. В державних університетах неповну вищу освіту, при здобуванні першої освіти здобуває 29\% студентів; при здобуванні другої освіти навчаються $14 \%$ студентів; $56 \%$ на заочній формі навчання і 1,1\% на дистанційній [6, с. 39].

Програма неповної вищої освіти відіграє важливу роль. Починаючи з 1980 - х років кількість студентів, які навчалися за програмою неповної вищої освіти збільшилася. Спочатку неповна вища освіта мала місце у денних формах навчання, а починаючи з 1992 року почала діяти в програмі другої освіти та дистанційного навчання. Таким чином у 1983 році 35 тисяч студентів здобували неповну вищу освіту, а вже у 1990 році їх кількість стала 71 тисяча, у 2000 році - 424 тисячі, у 2003 році - 1 млн. 500 тисяч.

Студенти пропорційно на рівні неповної вищої освіти навчаються у таких університетах як Namık Hemel Üniversitesi - 65\% студентів; Mersin Üniversitesi - 48\%; Mustafa Hemel Üniversitesi - 47\%; Adnan Menderes Ünıversiti - 45\%, у таких університетах як Afyon Kocatepe, Celal Bayar, Süleyman Demirel, Kocaeli Üniversitesi - 40\% студентів навчаються на неповній вищій освіті [6, с. 43].

Починаючи з 1992 року почалася діяльність таких освітніх рівнів як неповної вищої і повної вищої освіти у програмах другої освіти. У 1992 році на другій освіті було 11 тисяч 500 студентів - 2,3\% були на стаціонарі. У 2000 році на другій освіті було 207 тисяч, 3 яких 21\% навчався на стаціонарі. Кількість студентів, які здобувають неповну 
та повну вищу освіти за 2013-2014 рр. окрім заочної форми навчання є 2,9 млн, а кількість тих, хто здобуває другу освіту є 654 тисячі - це є $23 \%$, окрім заочної форми.

Отож, для майже половини студентів, які здобувають вищу освіту, здобувають іiі як другу у 21 державних закладах. Майже половина 3 цих університетів була створена у 1992 році. У цих університетах навчається одна третя тих, хто вчиться на стаціонарі - це є 661 тисяча студентів. Щодо дистанційної форми навчання, то це $є 1,7 \%$, тобто 50 тисяч. Тут навчається більша кількість хлопців, ніж дівчат.

У 1980 р., із збільшенням попиту здобуття вищої освіти, спостерігається еволюція розвитку заочної форми навчання. 3 1982-1983 рр. заочне навчання стартувало в університеті Eskişehir Anadolu. У 1992 році заочний факультет (Açıköğretim Fakültesi) почав урізноманітнювати напрямки підготовки за програмою неповної вищої освіти. На сьогоднішній день у таких трьох державних університетах як Anadolu, Erzurum Atatürk та Стамбулі є заочний факультет. Для порівняння, у 1982 році, тих, хто навчався на заочному факультеті було 27 тисяч, у 1990 році їх стало 68 тисяч, у 2000 р. - 120 тисяч, у 2012 р. - 200 тисяч.

Відповідно до гендерної політики, у 1980 - х роках по програмі повної вищої освіти навчалося 70-78\% хлопців і 20 - 25\% дівчат. На сьогоднішній день спостерігається поступове збільшення частки жінок у навчанні - 42\% і зменшення кількості чоловіків - до 58\%.

Оскільки в останні 30 років вища освіта в Туреччині постійно зростає і покращується, академічні кадри вміщують технічне і стратегічне планування, а додатково соціальні та етичні проблеми. Через науковий і технічний прогрес, кількість і кваліфікація вчених вказувала на їх збільшення. Так як Туреччина не була однією з десяти економічно розвинутих країн, для досягнення цілі в академічному кадровому забезпеченню, планувалося до 2013 року і що ВВП буде 3\% й весь час кількість зростатиме. Для того, щоб кваліфіковані випускники вищих навчальних закладів хотіли там викладати, мала бути сильна конкуренція.

У 2013 році у закладах вищої освіти працювало 133 тисячі 088 освітніх працівників. 3 них 45\% члени професорсько-а складу: це 18 тисяч 985 професорів, 11 тисяч 831 - доцентів, 29 тисяч 614 асистентів (yardımcı doçent). Інша група були наукові співробітники, експерти та викладачі - 55\%. В установах вищої освіти є 41 тисяча 362 молодших 
наукових співробітників, 18 тисяч 278 викладачів, 9 тисяч 505 лекторів [6, с. 46]. У процентах це - 14\% професорів, 9\% - доцентів, 22\% асистентів, 31\% - молодший науковий співробітник, 14\% - викладачів, $7 \%$ - лекторів. 13\% освітніх кадрів працюють у приватних університетах. Відповідно до 2000 року у 2013 році кількість освітніх кадрів і в державних, і в приватних університетах у два рази зросла.

Впродовж 1984-2000 років кількість членів професорсько-викладацького складу 37 до 23 тисяч зросла, а от частка освітніх кадрів була між 33 і 35\%. Не зважаючи на збільшення освітніх кадрів і членів професорсько-викладацького складу, у Туреччині на початку 1980-х років темпи зростання студентів залишалися низькими. Після 2000 року через тенденцію збільшення кількості членів професорсько-викладацького складу, кількість студентів теж збільшується. У 2012 році на одного освітнього фахівця кількість студентів зросла від 17 до 21\%. Щодо кількості членів професорсько-викладацького складу спостерігається перехід від 45 до 48\%. Якщо порівнювати ситуацію в Туреччині з країнами, які входять до Організації Економічного співробітництва та розвитку (Франція, США, країни Євросоюзу, Швейцарія, Норвегія, Японія та інші), то кількість є нижчою на 15, 6\%.

Починаючи з 2012 року збільшилася кількість тих, хто навчався за аспірантськими програмами. У 2013 році у Туреччині вчилося 68,8\% аспірантів і 69\% у докторантурі. Проте через те, що в регіонах Чорного та Середземного моря, Сх. та Півд-Сх. Анадолу університети були порівняно молоді, кількість аспірантів було доволі невеликою. Понад 7 тисяч аспірантів навчалося в університетах Стамбулу (Технічному ун-ті), Анкари, в у-ті Ататюрка, Докуз Еулюля, Сельджуку, Хаджетепе та Сакарья. Більше 5 тисяч аспірантів вчилося в університетах Сулеймана Деміреля, Ерджіес, Їлдіз Текнік та Караденіз Текнік. В порівнянні з державними університетами, кількість аспірантів у приватних університетах (Yedi Tepe, Bilkent Fatih, Sabanc1, Koç, Bahçeşehir) була нижчою, ніж в державних (İst. Bilgi - İstanbul Bilgi; İ. D. Bilkent üniversitesi - İhsan Doğramacı Bilkent üniversitesi; THK - Türk Hava Kurumu üniversitesi; H. Kalyoncu - Hasan Kalyoncu üniversitesi) [6, с. 47]. А щодо приватних університетів, то в середньому один університет в рік випускає 46 аспірантів, а ще два - 26. Проте є ще 30 приватних університетів, які ще не готують аспірантів. 
У Туреччині впродовж 1982-2012 років різні наукові ступені отримали 65 тисяч осіб, з яких 36 тисяч отримали в останні роки. У 1982 році їх було 663, а в 2012 р. їх стало 4506, оскільки спостерігається збільшення випускників докторантури у сфері соціальних наук (12\%), технічних (19\%), математичних і природничих (13\%). Науковим співробітникам, які публікувалися у міжнародних публікаціях установа Турецьких наукових і технологічних досліджень (TUBITAK) виділила їм на заохочення та винагороди 26 млн. турецьких лір.

До прикладу в Туреччині за рік налічується 4 тисячі випускників докторантури, в той час як в США їх є 61 тисяча, Росії - 27 тисяч, Німеччині - 25 тисяч, Японії та Англії по 17 тисяч. Відповідно до даних організації Економіки співробітництва і розвитку, частка Туреччини є $1,6 \%$, тоді як частка США - 28,6\%; Німеччини - $11,5 \%$; Англії - 8,3\%; Японії - 7,9\%; Італії - 4,8\%.

\section{7. Висновки}

Загалом можемо сказати, що на сучасному етапі в Туреччині спостерігається швидка інтернаціоналізація, яка проявляється у мобільності студентів; транскордонності освітніх кадрів, яка зростає; збільшенні наукових досліджень через міжнародне співробітництво; розширенні співпраці з Північною Америкою, Азією та Європою; зростанні частки спеціального фінансування і такого, що базуватиметься на особистих досягненнях. Цікавим $€$ той факт, що найменша кількість студентів, які виїжджали за кордон для здобуття освіти є у США $(0,1 \%)$, а найбільше в Ісландії- $19 \%$, а от в Туреччині є $3 \%$.

На перспективу, політика вищої освіти у Туреччині вказує на перехід з кількісного на якісне зростання, розвиток академічних джерел, міжнародну вищу освіту. В останні 60 років грамотність населення у Туреччині зросла 330 до 95\%. В індустріалізованих країнах до вищої освіти почали приходити у 1960-70-х роках, а в Туреччина це відбулося після 2000 року. Отож, нам вдалося спостерігати такі важливі тенденції в світовому освітньому просторі і зокрема в Туреччині, а саме:

- повсюдна орієнтація більшості країн на перехід від елітної освіти до загальнодоступної високоякісної освіти; 
- поглиблення міждержавної співпраці в галузі освіти. Активність розвитку цього процесу залежить від потенціалу національної системи освіти й від рівних умов партнерства держав та окремих учасників;

- істотне збільшення у світовій освіті гуманітарної складової загалом, а також завдяки введенню нових наукових і навчальних дисциплін, орієнтування на людину: психології, соціології, культурології;

- значне поширення нововведень за умов збереження сформованих національних традицій та національної ідентичності країн.

Туреччині є куди рости і розвиватися. А ми будемо уважно відзначати всі подальші зміни і висвітлювати у наших наступних працях.

\section{Список літератури:}

1. Київ - Стамбул: в освіті пліч-о-пліч. Київ, 2003. 84 с.

2. Колодій I.C. Державна освітня політика : курс лекцій. Львів : Видавництво Львівської політехніки, 2014. 156 с.

3. Akyüz Y. Türk Eğitim Tarihi. Ankara, 2015. 530. p

4. Çetinsaya G. Büyüme, kaliteli, uluslararasılaşma: Türkiyenin yükseköğretimi için bir yol haritası. Yükseköğretim Kurulu Yayın. 2014. No. 2, pp. 47-54.

5. Doğramacı İ. Fikirleri Türkiyenin Yükseköğretimi hakkında. Üniversite Araştırmaları Dergisi. 2018. No. 1(3), pp. 132-138.

6. Ertepınar A. Türkiye'de Yükseköğretime genel bir bakış. İnşaat Mühendisişliği eğitimi Sempozyumu. Antalya, 2014, pp. 31-47.

7. URL: https://uafrontier.com/vyshi-navchalni-zaklady-ta-kilkist-studentiv-vukrajini-1991-2014-2/

\section{References:}

1. Kyjiv - Stambul: v osviti plich-o-plich (2003). Kyiv, 84 p.

2. Kolodij I.S. (2014). Derzhavna osvitnja polityka: kurs lekcij. Ljviv: Vydavnyctvo Ljvivsjkoji Politekhniky, $156 \mathrm{p}$.

3. Akyüz Y. (2015). Türk Eğitim Tarihi. Ankara, 530 p.

4. Çetinsaya G. (2014). Büyüme, kaliteli, uluslararasılaşma: Türkiyenin yükseköğretimi için bir yol haritası. Yükseköğretim Kurulu Yayın, no. 2, pp. 47-54.

5. Doğramac1 İ. (2018). Fikirleri Türkiyenin Yükseköğretimi hakkında. Üniversite Araştırmaları Dergisi, no. 1(3), pp. 132-138.

6. Ertepınar A. (2014). Türkiye'de Yükseköğretime genel bir bakış. İnşaat Mühendisişliği eğitimi Sempozyumu. Antalya, pp. 31-47.

7. URL: https://uafrontier.com/vyshi-navchalni-zaklady-ta-kilkist-studentiv-vukrajini-1991-2014-2/ 